\title{
Patriarchy in the Digital Conjuncture: An Analysis of Google's James Damore
}

\author{
Ben Little (UEA) and Alison Winch (UEA)
}

\begin{abstract}
:
Our case study looks at the events surrounding the sacking of Google engineer James Damore who was fired for authoring a memo which stated that women are biologically less suited to high-stress, high-status technical employment than men. Damore, asserting that his document 'was absolutely consistent with what he'd seen online', instantly became an ambivalent hero of the alt-right. In the media furore that followed, surveys indicated widespread support for Damore's position within the tech industry. Like the men who own and run the companies of Silicon Valley, the software engineer subscribes to the idea that the world can be understood and altered through the rigorous application of the scientific method. And as he draws on bodies of knowledge from evolutionary psychology and mathematical biology, we see how the core belief structures of Silicon Valley, when transferred from the technical to the cultural and social domain, can reproduce the sort of misogynistic 'rationalism' that fuels the alt-right. We argue that Damore's memo is in line with Google's ideology of 'dataism': that is the belief that the world can be reduced to decontextualized information and subject to quantifiable logics. Through its use of dataism, the memo reveals much about the similarities and continuities between Damore, the ideas laid out in his memo, and Google itself. Rather than being in opposition, these two entities are jostling for a place in the patriarchal structures of a new form of capitalism.
\end{abstract}

\section{Patriarchy in the Digital Conjuncture: An Analysis of Google's James Damore}

To understand the transformations wrought by the emergence of digital technologies and digital culture, we must also understand the points of contestation taking place within the cultures of production in the digital monopolies that have come to dominate the economic and ideological horizons of the post-crash global north. Our case study of James Damore, a sacked Google employee turned right-wing micro-celebrity, here may seem marginal at first 
glance, but within it we can see the orientation of struggle within primary tech culture (the culture of programmers and technologists as opposed to that of users and consumers) and start to assess what that may mean for wider ideological transformations. In this article we suggest that some key points of contestation are those taking place between the so-called liberal founders of tech monopolies (also the richest people in the world), and the alt-right a digital era phenomena that Annie Kelly describes as 'a network of smallish digital social hubs whose ideological position can be understood as the natural conclusion of neoconservative logics surrounding liberalism, manhood and national security'. ${ }^{i}$ Forms of 'popular misogyny' can also intersect with these hubs. ${ }^{i i}$ A conjunctural analysis allows us to zoom out and observe how these contestations dominate the political terrain, and we argue that these contestations are over the re-entrenchment of patriarchy.

We start with a meme that circulated in support of James Damore, a former Google employee 'fired for truth' over a memo in which he suggests that gender inequality in the workplace has its roots in biological differences. iii The meme depicts Damore as the protestant professor of theology, Martin Luther (1483-1546).

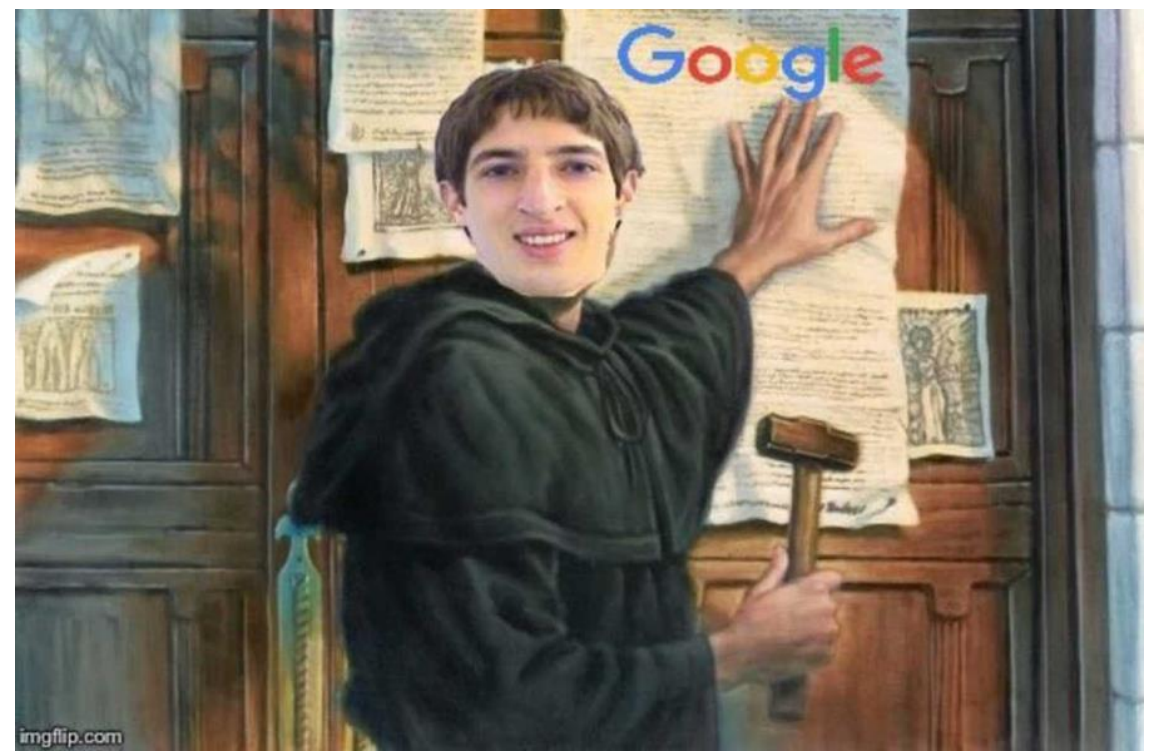

Following the memo's leak, Damore was sacked by Google; its CEO Sundar Pichai deeming its views 'not okay'. iv In the media furore that followed, surveys indicated widespread support for Damore's position within the tech industry. For example, one poll of 441 Google staff indicated $50 \%$ of respondents agreed with it. ${ }^{\vee}$ Moreover, Damore was appropriated by a number of different figures across emergent right-wing subcultures, from evolutionary 
psychologists to alt-right celebrities to YouTube anarcho-capitalists. Significantly, he was interviewed by three key figures of the alt-right: Milo Yiannopoulos, Stefan Molyneux and Jordan Peterson. Damore describes himself as a 'huge fan' of Peterson as well as Molyneux, and as such he reflects their views, values and rhetoric in his memo (although he doesn't cite them directly preferring to use Wikipedia). ${ }^{\text {vi }}$ He becomes a visible symbol of their influence outside of their alt-right circles on YouTube. He is now currently suing Google (with the aid of Republican lawyers), alleging discrimination against white male conservatives.

Damore and his memo make a productive case study in assessing the political terrain of digital capitalism because on the face of it, it looks like Damore (and the alt-right) are at odds with Google, its founders and its ideology. For the alt right, Damore is Martin Luther to Google's Vatican: he speaks truth to power pinning his memo to the message board of their holy sanctum - their brand's progressive media image. We want to argue here, however, that the memo reveals much about the similarities and continuities between Damore, the ideas laid out in his memo, and Google itself. Rather than being in opposition, these two entities are jostling for a place in the patriarchal structures of a new form of capitalism. Because he is a self-declared Google fanboy, Damore is a product of Google in more than one way. He comprises the core demographic of their workforce (white, heterosexual, male, cis, went to prestigious universities like MIT and Harvard). More than this, however, his memo is also in line with Google's ideology of 'dataism': that is the belief that the world can be reduced to decontextualized information and subject to quantifiable logics. We analyse the ideology of dataism below, but first turn to a discussion of the digital conjuncture.

\section{The Digital Conjuncture}

Thinking about 'conjunctures', a word derived from the latin verb conjungere meaning 'drawn together' (and in other contexts 'married'), has a long history in critical approaches to politics: originating in Lenin's revolutionary strategy, it became a distinct idea in Antonio Gramsci's Prison Notebooks and came to maturity as a primary mode of British New Left political critique in the writings of Stuart Hall. vii This etymology and conceptual history are important to recognise, as this approach indicates a bringing together of seemingly disparate elements of a historical moment to open space for political intervention. Thus, 
conjunctural analysis seeks to understand contemporary political currents as an interconnected whole. On one level this is an impossible task with too many variables to consider fully in a single text or even collected group of writings, but on another level, it has produced some of the most robust and insightful political commentary of the last forty years. Conjunctural analysis in the work of Hall and his collaborators has produced concepts such as 'authoritarian populism' and a sustained critique of British neoliberalism in the pages of Soundings journal, intellectual work that has continued valence in an era of Trump and Brexit. viii

Nevertheless, the approach can seem lacking in precise methodological operations to some in the social sciences. It often has a literary tone, reading across different social locations to posit both motivation and symbolic significance to a variety of historical agents, both human, institutional and abstract. As much an analytic sensibility as a mode of research, it both draws upon Marxist critical theory and rejects its potentially rigid structures. As Jo Littler argues, conjunctural analysis is theoretically eclectic and anti-disciplinary:

Work which seeks to be "conjunctural" in character might draw from the psychosocial; some on feminist activism; some on literary analysis; others on philosophy. All would try to use this multi-faceted investigation to consider the configurations of power which constitute contemporary life. ${ }^{\text {ix }}$

Conjunctural analysis has also consistently been concerned with the question of periodisation which motivates so much contemporary debate: do we still live in the "neoliberal conjuncture" for instance? As Doreen Massey and Mike Rustin state, thinking conjuncturally involves 'a periodisation of society as a whole that takes its shape out of the interweaving of different elements (social, cultural, economic), which often individually have different temporalities. ${ }^{x}$ Now, we argue, our task lies in perceiving a digital conjuncture, 'as it [is] happening,' but we must also be thinking of the histories that work upon and within the present. ${ }^{\mathrm{xi}}$ For example, histories of race and oppression, gendered rereadings of the 'great man' narratives of western civilisation, as well as mutations within imperialism and capitalism; all these locate the arrival of digital technologies within specific contexts and bear relation to the uneven movement of cultural and economic power. Digital technologies do not emerge complete on some social tabula rasa, they are located in these histories and shaped by them. Yet the transformations wrought, not despite of, but because 
of their historical situatedness, are profound enough to characterise the present. In the words of Robin Murray: 'We are living at a time of profound economic and social transformation which is leading to the redrawing of the economic and institutional map. I have referred to this as the Age of Google.'xii

Filling a gap left by the discredited finance industry in the wake of the crash, but in alliance with it, Big Tech's global dominance is now widely recognised. ${ }^{\text {xiii }}$ Although we use the term digital capitalism, we situate our conjunctural analysis in critiques of a 'platform society'xiv and 'surveillance capitalism' ${ }^{\mathrm{xv}}$ Following Shoshona Zuboff and others, we recognise that this form of capitalism is new and that it is both shaped by, and reshaping, social relations in profound and dramatic ways. The Big Tech firms are not simply businesses, but platforms for a transformed sociality bidding to be the foundations of civil society, the terrain of political debate and struggle, and facilitators of new modes of shopping and consumption: and all at the same time. Big Tech is also a key source of American soft power: the McDonalds of the post-crash world spreading American values and economic influence around the world (even as we suspect that overconsumption of its products are probably not very good for us). The emerging, but contested, hegemony of Big Tech is at the heart of a post-crash ideological transformation and, as we will see, is profoundly reshaping the foundational epistemic architectures that frame the social production and dissemination of knowledge. ${ }^{\text {vi }}$

One of the key aspects of this social, political and economic transformation is the concentration of power and resources in ever smaller locations, both geographically and virtually. xvii This means that we can see many of the contours of this new focus of power by looking at a small number of technology firms, largely based in the San Francisco Bay area (metonymically referred to as Silicon Valley due to the high concentration of firms in the Santa Clara Valley) and more broadly the West Coast of the United States (to include companies like Microsoft and Amazon in Seattle, and Tesla in Los Angeles). Significantly, all the founders of the most powerful corporations in the tech industry - Apple, Microsoft, Oracle, Amazon, Google, Facebook, Space X/Tesla- are white men. ${ }^{\text {xviii }}$ All these men are idiosyncratic social actors, yet they are largely unremarkable people given the contexts from which they emerged. We argue that by analysing the men who establish, own and run these 
companies, as well as the ideological structures they inhabit and the cultural and political phenomena that have emerged as a result, we can identify the leading direction of this digital conjuncture. ${ }^{\mathrm{xix}}$

Our intervention in the academic debates surrounding digital capitalism, as well as those focusing on online misogynies, is that we make connections in a conjunctural way between these founders - the richest people in the world and the misogyny of the alt-right. More than this we re-deploy 'patriarchy' as a 'struggle concept' in order to make sense of the male-dominated networks and structures that hold the power on the West Coast of America. ${ }^{x x}$ In doing this, we build on work that argues that Google reinforces racism through the structures of its search engines and algorithms; ${ }^{x x i}$ its status as a monopoly corporation; ;xii and its immense encroachment into the site of the university and the library in its bid to index and produce 'the world's knowledge'. ${ }^{x x i i i}$ In the links that we make between patriarchy, sexism and online misogyny we develop the work of Kate Manne, Debbie Ging, and Sarah Banet Weiser. Using conjunctural analysis, this article argues that we are seeing a re-entrenchment of an imperial form of patriarchy that is stratified along the lines of race and class. This re-entrenchment is contested and resisted, and we can (partly) see this in the rise of 'popular feminism' or 'neoliberal feminism', but also other more radical sites of activism. ${ }^{\text {xiv }}$ In this article, however, we examine the contestations over the place of men in these patriarchal structures.

On the surface, James Damore is an unlikely hero for the alt-right. An archetypically nerdy (former) employee of Google, a company that presents itself as the progressive heart of the tech industry, Damore seems to embody the opposite of the alt-right's 'idealised model of white masculinity, based on nostalgia for a time that has never existed' ${ }^{x x v}$ And yet, it turns out he might be highly representative of one of their key constituencies: technically savvy but socially disenfranchised young men. Damore's firing from Google feeds a narrative on the conservative right in the US, that the tech industry is responsible for the suppression of conservative (and therefore patriarchal) views. Indeed, companies that run Silicon Valley, a supposed hot bed of immoral liberalism, are themselves seen as part of a wider problem of degenerate values in California, home of both Hollywood and the counterculture. (Even though, as we argue here, these supposedly radical values are much more conservative in 
relation to gender, race, class than their ideology may at first appear). At their most extreme, these ultra-conservative critiques become white supremacist, anti-semitic conspiracy theories about Jewish domination of the media, but more generally they sit in the familiar space of the American culture wars and assert, as Damore has done, that in companies like Google, heterosexual white men are discriminated against due to the hegemony of ideas around social justice. On one level, this is not new. ${ }^{\text {xxvi }}$ What is new however is their location not within Hollywood or 'the mainstream media', although those accusations continue, but within the world of the digital, a space that is allowing new political formations to emerge with a rapidity than can be disorientating. At the time of writing, the formation on the political right of digital culture seems growing in confidence and power.

\section{Why Martin Luther?}

Damore is not the only high profile tech figure to be compared to Martin Luther. ${ }^{\text {xxvii John }}$ Naughton (Observer tech columnist and Cambridge don) also tried to set himself up as a contemporary Luther through his website 95theses.co.uk. In terms of our questions about conjunctural periodisation the comparison is worth dwelling on, and we unpack the recurring figure of Luther throughout the article. Luther, a professor of theology at the University Wittenberg, became a symbol for a profound process of change in European society. Luther's theses, ostensibly about the corruption of Papal indulgences, demonstrated not just the thick links between Renaissance humanism and an emerging critical theology, but also how the new communication technology of print enabled universities to become the institutions that would overtake monasteries as the principle guardians of the production, storage and dissemination of abstract learning. In addition, as Naughton puts it, the publication of the theses was 'the event that triggered a revolution in religious belief, undermined the authority of the Roman church, unleashed ferocious wars in Europe and shaped the world in which most of us (at least in the West) grew up.' ${ }^{\text {xxviii }}$ Luther became heavily involved in the new profession of publishing to disseminate his ideas and helped establish Wittenberg as a key centre of the new industry. He also made a clean break with established scholarly tradition and wrote in German instead of Latin bringing 'complex theological ideas to be presented to a non-specialist audience', allowing a far wider public to engage in profound matters of theological debate. ${ }^{x i x}$ 
Anticipating that communications technologies will deliver a similar shift to the Gutenberg revolution is not new, ${ }^{\mathrm{xxx}}$ but by holding tightly to the comparison with Luther we are invited to consider the parallel with some precision. From the greater access to knowledge that previously lay hidden in universities and libraries, but is now available through an eponymous company's search engines, to a new public sphere and attendant political heresy (from Trump and Brexit to Corbyn and Podemos), to the shifting socialities of social media; the scale of transformation being asserted here might similarly be the beginning of the complete reorganisation of society: technologically, culturally, socially, economically.

With this in mind, while we have suggested that the comparison between Damore and Luther is provocative, it is also patently ridiculous and only works when the myth of Luther's theses is invoked. According to historian Andrew Petegree, the theses were pinned to the door of Wittenberg's church, not as a symbolic challenge to the Vatican's authority, but because the church was where the town's university held its academic debates. ${ }^{x x x i}$ It was a note that advised participants about the topic of discussion. Printed copies would also be disseminated inside, much like a flier might be distributed in a faculty to advertise a debate, or a memo might be circulated at a company to spark discussion about an issue of corporate interest. This demystification changes how we read the analogy. In this reading, Luther, like Damore, is an ordinary scholar who happened to opportunistically capture a profound moment of historical change. But he was also taken up by western narratives which privilege the role of particular white men as the drivers of history. Popular historical narratives are not conjunctural, they marshal individuals as heroes or geniuses in order to justify (or occasionally challenge) present orthodoxies. What is telling about the Damore memo, is not its exceptionality, but its banality. And that makes the great significance ascribed to it, and the hundreds of articles and discussions triggered by it, all the more interesting. Why was a fairly uninspired, confused - 'I hope it's clear that I'm not saying that diversity is bad' - sexist memo given so much attention? ?xxii $^{x}$

\section{Google's Epistemic Architecture}

Google and the alt-right are different kinds of entities. One is a corporation, and the other is a loose online network that uses, among other technologies, Alphabet-Google's platforms 
(especially YouTube) to disseminate, share and collaborate over 'conservative viewpoints'. Our argument here is that, although it seems like the alt-right and Google are at odds, they are not as polarised as it might seem; not least because Alphabet-Google owns YouTube. Google was founded by Larry Page and Sergey Brin, at the time two 'genius' young researchers at Stanford university whose Jewish backgrounds, early experiences of migration and exposure to radical progressive politics mark them as natural opponents of the alt-right. Yet their company is both defining of a dominant strand within tech culture and typical of it, a strand that has facilitated the rise of radical reactionary politics online. Google is a company built upon both the data generated by its users and at the same time the largest index of publicly available information ever compiled. While organisations like Facebook, Twitter, and Tumblr are spaces where activism can thrive (as well as politics of hate and oppression), Google's utopian claims, through its mission statement, are primarily tied to making information available and accessible. Their slogans are: 'To organize the world's information and make it universally accessible and useful' and 'don't be evil'. Google's indexing of human knowledge spans websites, books, images, academic articles, places, and more. While this is of democratising potential, it is not only the product of a process that inherently privileges some perspectives over others, but is also the paradigmatic exemplar of the data economy. The Google search engine, is not simply an index, but a new mode of disseminating and legitimating data that is at the heart of digital transformations of the social: that is, Google, its search engines and its other platforms that organise information (such as YouTube), provide the epistemic architecture of a digital society.

Safiya Umoja Noble argues for understanding the Google search engine partly through how it represents people. She discusses the detrimental impacts of assuming the 'colourblind' algorithm on Black women and girls in the United States by examining the various ways that Google harnesses and deepens racist structures through its indexing of information and its algorithms. She contextualises Google as a key participant of the American imperialist project that profits from the bodies of Black people across the world: from the mining of colton in the Congo, to the dismantling of e-waste in Ghana, to its bypassing of labour unions in its manufacturing activities. This provides the backdrop to her focus on the Google search engine as a highly value-laden form of indexing. ${ }^{x x x i i i}$ 
Although many people regard Google as a public resource, Noble notes the importance of emphasising that the Google search engine is primarily an advertising company. AdWords, search engine optimization, crawling and algorithmic indexing all mean that the knowledge is commercially driven. Contrary to those who argue for the utopian potential of Big Tech such as Peter Diamandis and Steven Kotler, ${ }^{\text {xxiv }}$ Noble argues, 'Commercial search, in the case of Google, is not simply a harmless portal or gateway; it is in fact a creation or expression of commercial processes that are deeply rooted in social and historical production and organization processes. ${ }^{\prime x x v}$ In addition, although the search engine does not necessarily know who the searcher is, it does aggregate us with people who have similar digital traces. ${ }^{\text {xxvi }}$ Moreover, Google blocks sites that compete with it. These factors mean that the information retrieved is not adequately contextualised, but is instead delivered as apparently neutral or objective. Indeed, this naturalisation of knowledge is precisely what Google aims for as it doesn't culturally locate the information generated. As Noble persuasively argues, indexing is a human project, one that is squarely located in the white supremacist patriarchy of American imperialism. ${ }^{\text {xxvii }}$ This value-laden taxonomical work is encoded in algorithms and delivered to us through digital platforms and the code that is written by people, people like James Damore.

Google dominates the digital realm, 'the victor in the winner-take-all race to serve as the chief utility for the World Wide Web.. ${ }^{\text {xxxviii }}$ And for all the public good, the overall effect of Google's presence in the digital sphere is: 'inherently conservative... winners keep winning. ${ }^{\text {xxix }}$ Its search algorithms reward not some intrinsic value or arbitrary measure of quality, but popularity measured by the number of links to the sites that link to a given page. Google search applies measures of quality designed to facilitate the filtering out of low quality academic articles (the PageRank algorithm and its descendants) to the wider social sphere. While in the abstract this might seem like it would produce a relatively value neutral system, in practice the search algorithm embeds a highly conservative epistemic architecture at the heart of the world-wide-web's knowledge distribution mechanisms. This is because by using popularity as a proxy for quality in assigning significance to digital content, Google's algorithms reinforce the pre-existing dominance of 'common sense' ideas 
about, for instance, race, class and gender. Thus, this architecture reinforces patriarchal and racially hierarchised ways of configuring the social.

Indeed, a reassertion of patriarchal privilege is one of the transformations at the heart of the digital conjuncture. This isn't to say that other conflicts that are also given space and expression in digital culture are not equally as important, but rather that gender and race cut across these intersecting struggles in a specific and revealing way. Since the utopian screeds of the internet in the 1990s promised liberation from race and gender ('this is not where bodies are ${ }^{\prime x \mid}$ ) and the way that this was taken up by, for example, Henry Jenkins in the early 2000s, there has been a common understanding the digital is a space of freedom. ${ }^{x l i}$ These discourses universalise the user as they dematerialise them: ultimately reproducing the problem identified by Imani Perry as that of enlightenment sexism and racism embedded in the abstract category of personhood (as defined by philosophers like Hobbes and Locke). ${ }^{\text {lii }}$ Thus, without having an intersectional approach to the internet (who has access to a computer, who knows how to code, who has the privileges of public speech, who has awareness enough to mitigate pervasive racism and sexism in the culture) then the utopian project of the early internet was bound to fail. As Google reflects back the social hierarchies that it is situated in, then as Noble argues, the gaze it promulgates is primarily white and male.

\section{Google and Diversity Work}

Damore's memo states that women are biologically less suited to high-stress, high-status technical employment than men. Although he critiques 'diversity' throughout, his evidence base is linked to the differences between men and women. His main argument proclaims that '[o]n average, men and women biologically differ in many ways', and that these 'differences may explain why we don't see equal representation of women in tech and leadership'. He notes that:

These [biological] differences aren't just socially constructed because:

- They're universal across human cultures

- They often have clear biological causes and links to prenatal testosterone

- Biological males that were castrated at birth and raised as females often still identify and act like males 
- The underlying traits are highly heritable

- They're exactly what we would predict from an evolutionary psychology perspective $\mathrm{e}^{\mathrm{xliii}}$

More than this, he argues, that diversity initiatives are disingenuous: 'Discriminating just to increase the representation of women in tech is as misguided and biased as mandating increases for women's representation in the homeless, work-related and violent deaths, prisons, and school dropouts.' He goes on to argue that because of this, diversity initiatives comprise an 'ideological echo chamber' that exclude conservatives and dissenting voices who prefer their highly paid workforce white, middle class and male. Throughout the memo, he hyperlinks to internet sources in an attempt to provide scientific evidence that gendered differences 'aren't just socially constructed'. These sources are confused and specific to Damore's ideological adherence to evolutionary psychology, a discipline which numerous feminist scholars have argued serves to preserve and naturalise patriarchy. ${ }^{x l i v}$ Damore's sources range from Wikipedia, to blogs, conservative internet outlets and academic psychology journals that can be read in a manner sympathetic to popular renderings of evolutionary psychology. ${ }^{\text {lv }}$

So, how does Google stand on diversifying its workforce? Google, in its early days, arguably did more to address gender inequality than any other Silicon Valley company. With processes in place to encourage the recruitment of female programmers and executives, the early Google managed to produce three of the most powerful women in the tech industry: Marissa Mayer, Sheryl Sandberg and Susan Wojcicki. Yet as Emily Chang reports, as Google grew 'it defaulted to recruiting methods that were more standard in the industry' and which focused on hiring according to the archetype of the 'brogrammer' a twenty-sixyear-old, socially awkward coding savant. Likewise confrontation, framed as robust debate ('you need dissent' says Alphabet chairman Eric Schmidt), was seen as a key leadership skill and Chang's interviewees suggest that the company developed a reputation for an aggressive work environment and many women simply stopped applying. ${ }^{\text {xlvi }}$ In a blog post titled 'It sucks to be a woman in tech', a former employee recently estimated that in the key software engineering teams, Google has as few as $5 \%$ women engineers as opposed to the $20 \%$ they claim in their official figures. xlvii 
Google is currently being sued for ageism and sexism by women employees and the government. These are court cases that, at the time of writing in spring 2018 , seem to have more mileage in the courts than Damore's class action suit (update: indeed Damore exited the case in favour of arbitration in 2019). Furthermore, reports are conflicting about the origins of Google's diversity programme. Buzzy PR pieces by journalists such as Fortune's Ellen McGirt conflict with inside accounts (see for instance surveys done by Christian Fuchs on work-life balance). ${ }^{x l v i i i}$ Other promotional writing is also contradictory, stating the founders both wanted to hire clones of themselves as well as more women. ${ }^{\text {lix }}$ Ultimately, Google does have unequal workplace demographics ( $80 \%$ male in tech positions; $25 \%$ of leadership roles are women; $2 \%$ of workforce Black). They mainly hire from prestigious universities like the ones the founders went to: Stanford, Berkeley, Illinois, MIT and thus reinforce a classed and raced dimension to their recruitment.' Moreover 'Black students are earning computer science degrees at higher rates than they are being hired by Silicon Valley companies' like Google. ${ }^{\text {li }}$

There is a vision statement on Google's diversity page, where CEO Pichai is quoted saying, 'A diverse mix of voices leads to better discussions, decisions, and outcomes for everyone.'lii And there is acknowledgement of the specifics of the problem, discussing a scandal where Google's image search algorithm started marking pictures of gorillas as Black people. As McGirt reports:

Bradley Horowitz who led Google Photos at the time... explains that if the team had been more diverse, it would have noticed the problems earlier in the process: 'To the degree that the data is sexist or racist, you're going to have the algorithm imitating those behaviors [...] It's the world we all live in, but it's Google's job to put its finger on the scale to make it level. 'liii

This, as well as a plethora of other incidences of decontextualised knowledge and dataism leading to sexist and racist outcomes - as discussed by Noble - reveals the effects of racialised patriarchal structures that recruit a workforce in the mirror image of the founders. ${ }^{\text {liv }}$ Indeed, Sara Ahmed argues that using the language of diversity, does not 'translate into creating diverse or equal environments'. Indeed, there is often 'a gap between a symbolic commitment and a lived reality'. Iv If Google are not going to seriously 
address their structural inequalities or work for social justice; if they are going to continue using the 'pipeline' as an excuse for their workforce, then their diversity pages are merely PR.

We can see that Google evidences Richard Barbrook's and Andy Cameron's early 1990s formulation of the Californian Ideology in maintaining racial hierarchies: that is the general exclusion of Black and Latinx people from the tech sector. Seeing a form of rationalist coffee house style belief in liberal democracy as at the core of the emergent values of Silicon Valley, Barbrook and Cameron (like Perry cited above), also saw it reproducing the contradictions of those eighteenth century liberals. Focusing on the particular influence of slave-owning president Thomas Jefferson, they frame the problem of the Californian Ideology through: 'Jeffersonian democracy [becoming] a hi-tech version of the plantation economy of the Old South.' As such, while conflicts around race are shifting within this new conjuncture, the strict hierarchies within the tech industry are, and have been, relatively stable over the last twenty years. East and South Asian people are well represented in the industry, while Black and Latinx are largely excluded from high status positions while making up a large proportion of the service staff - catering, maintenance and so on. These roles are often outsourced producing a racialised subclass who lack access to the high salaries, stock options and considerable benefits of those directly employed by technology firms. Furthermore, while representation of Asian men is increasing at executive level (for example Sundar Pichai CEO of Alphabet and Satya Nadella CEO of Microsoft hold two of the most powerful salaried positions in the industry), white people take the lion's share of the senior roles, particularly among the founders of the tech companies and the investment firms that support them. These investors believe deeply in the cult of the founder which forms the primary legitimating feature of the sector's financial and proprietary organisation: and these genius founders come from a limited pool that is primarily white or Asian and male. Insiders to this founder culture are aware of the problem but typically disavow it arguing that this pool is made up of those who 'are playing with computers when they are thirteen years old. "If you want to fix the problem, that's what you have to change." Ivi Google is heavily invested in this start-up culture, both literally in terms of investment and ideologically in relation to their own founders, Brin and Page, and the aspirations of many of 
their staff to set up their own billion dollar start-ups (perhaps eventually to be acquired by Google).

\section{The ideology of Dataism}

Now that we have broadly established that Damore's reactionary attitudes are not as incongruent with Google's practices as we might think, we explore what an ideology that works as well for overt conservatives as it does for apparent corporate champions of liberal values might look like. The overriding ideology at Google and to which, we argue, Damore's memo subscribes, is what José Van Dijck calls dataism, the 'widespread belief in the objective quantification and potential tracking of all kinds of human behavior and sociality through online media technologies'. Ivii Like the men who own and run the companies of Silicon Valley, the software engineer implies that the world can be understood and altered through the rigorous application of the scientific method. And as he draws on legitimated bodies of knowledge like evolutionary psychology, we see how the core belief structures of Silicon Valley, when decontextualized and transferred to the cultural and social domain, can reproduce the sort of misogynistic 'rationalism' that fuels the alt-right.

At Google, 'data' is seen as providing unexpected answers to difficult questions. In their advice to prospective hires, Eric Schmidt and Jonathan Rosenberg summarise its importance thus: 'Data is the sword of the twenty-first century, those who wield it well, the samurai. So start sharpening that blade, uruwashii, and take statistics.' 'viii Google's search engine can answer the gender dimensions of this statement. In a Google image search for 'samurai', we had to scroll through four pages before a picture of a woman appeared, and that was for a female martial artist and Ted Talk coach from California. ${ }^{\text {lix }}$ Furthermore, in most Google conference rooms there are two screens, 'one of them is for ... meeting notes. The other is for data. ${ }^{\prime \mid x}$ But data-oriented approaches are always partial: 'big data relies on what is available and obscures that which is not' ${ }^{\prime}{ }^{1 x i}$

Dataism is both Google's corporate ideology and Damore's. Google privileges an engineering perspective on the world - one which is undoubtedly important but also necessarily incomplete. According to Schmidt and Rosenberg, Google conducts itself in a way that is 'solution-orientated' with 'a bias towards data' in its decision making 
processes. ${ }^{\text {xii }}$ This position is ideological and can lead to the lack of cultural situatedness that we see in Damore's memo but also in Google's products. It is in service of the idea that 'subjective opinion' can somehow be eliminated. Ixiii It is the belief that with enough information, context can be flattened out and all information can become comparable and all decisions made objectively. Data is not neutral - it is always an applied form of knowledge gathered (i.e. removed from context) and organised in specific ways. So not only is data radically decontextualised knowledge, it is also constantly being recontextualised in the service of finding solutions to problems.

Thus dataism is both a set of concepts and values which people subscribe to and a practice. Indeed it is ideological in the sense that it enables the coordination of action without explicit collaboration. As both a universalised imaginary and a blueprint for action, it helps bind together dominant and subaltern groups within the hegemonic bloc forming around Silicon Valley. It shapes the actions of the founders, engineers, investors and users of tech products. And dataism works in specific ways that are processed by the institutions of the Valley. Problems are identified by the visionary, genius founders - a specific group of acquisitive entrepreneurs with an engineering mindset (like Brin and Page) - and products are then designed to solve that problem using data. The success of a given product is determined by the willingness of the founder-CEO to greenlight it or the Venture Capitalist funders to invest in it. Thus, founders and Venture Capitalists represent the two dominant class fractions of this bloc, while the subaltern class of jobbing engineers aspire to have the right idea to become the former, or join the right start-up, along with stock options, to become the latter. This whole business culture is endemically raced and gendered.

Damore stated in a media interview, that his memo and his intention were within the stated cultural expectations of Google. ${ }^{\text {xiv }}$ We agree with him. But culture is contested (as demonstrated by the "Google walk-outs" against sexual harassment in 2018) and difficult to measure, and where it is measured, under dataism, it becomes only that which can be measured. This perhaps explains why his memo struck such a chord. It both presented as evidence and robust dissent to the Google hierarchy in ways that are ostensibly desired, but what he said was culturally unacceptable. The inability of data to exhaust human interaction, shared culture or to meaningfully process history (and in this instance 
oppression as an historical force) is striking. This extends to Google's philanthropy which is 'Data-driven, human-focused philanthropy', a striking oxymoron. Ultimately "data" can be put to many uses, but is always insufficient in a human context. And yet, this paradoxical culture is, as far as we can tell, driven by Google's own 'visionary' founders Brin and Page who it is claimed have: 'a very disciplined, scientific approach to solving problems... [which means that] "information is the basis for almost all the decisions anybody makes"'.. ${ }^{x v}$

\section{The Privatisation of Knowledge}

Part of the reason why Damore's sources seem confused in his memo and random from an academic perspective is because he largely draws on sources sourced through Google itself. In doing so he constructs an argument that presents a datafied approach to evolutionary science (both biological and psychological) - as a sort of primary social science: radically extending the sort of claims the underpinning research can make: thus he fails to account for or understand the way in which historical force comes to bear on the present (i.e. he does not think conjuncturally). Because data sets have time series rather than histories, and information that is retrieved through search engines lack cultural situatedness or historical context, so Damore is able to make an equivalence between desire for more women in leadership roles at Google and a disinterest in homeless men /desire for more homeless women. In other words, he wonders why women would want to have more representation in tech while they are not demanding more representation as prison inmates. Obviously, this is a highly emotive rhetorical move typical of popular misogyny. Nevertheless, it also points to the pervasive white masculinism of the internet. In other words, because knowledge is delivered through the search engine without historical situatedness, then all knowledge becomes equivalent. More than this though, the knowledge that is retrieved mirrors the racialised patriarchal structures of the culture within which it is located.

Google (and the internet) then is to the contemporary university what the university in Luther's time was to the Catholic Church. It offers a new epistemic architecture, institutionalising the potential of digital technology in specific ways to reflect specific values. Lutherian Protestantism had specific values, ones which were not the only available 'heresy' at the time, but they were the most successful, the most transformative and, according to Petegree at least, the most closely aligned with the new technology of print. So too is the 
dominance of Google's infrastructure of knowledge, neither inevitable nor necessarily desirable, but it is shaping the current conjuncture. It presents its 'organisation of the world's knowledge' as neutral, thus perpetuating whiteness as a privileged category, as a form of epistemology. Ixvi This can have a direct effect in what counts as legitimate knowledge for its users. As Vaidhyanathan argues, this is based in an almost religious trust in the company to deliver reliable results. ${ }^{\mid x v i i}$ Noble also discusses how this intervention into the realm of the library and university has various negative effects on Black women and girls.

In contrast, some advocates of a digital knowledge economy, barely recognise universities as having a research or social function. Technologist and educational theorist Ryan Craig in his 2015 book College Disrupted sees this as a sector ripe for the disruptive application of dataism. He sees universities as institutions that need 'unbundling', separating out their various social, educational and consumer functions to reduce costs and ensure that student 'return on investment' is maximised by only selling them the parts of the college experience they desire and thus ensure that their educational purchases can align with their desired career trajectory. Data is the thing to do this, according to Craig Ixviii.

Vaidhyanathan suggests, because state and public institutions have been so hampered by the neoliberal assault on their social roles, so Google takes advantage of the potential of digital technologies in their fields. This is because, for instance, universities have been unable to take proactive steps themselves. In such a way the so-called 'democratisation of knowledge' immanent in the advent of the digital era also becomes the privatisation of knowledge. ${ }^{\text {Ixix }}$ Damore is a product of this system of higher education. We can revisit the link between Google and Luther here. Luther was assisted in his challenge to the church through the protection of the Augustinian monastic order of which he is a member. Nor did he destroy the church, but instead enabled its fragmentation with an endurance that previous heretical movements could not sustain. This is largely a function of vernacular print allowing theological debate to take place among the laity. In a similar vein, Google is assisted in their transformation of the internet's indexing function by the commercial imperatives placed on the university system. They in turn reshape the organisation of knowledge within universities to better serve commercial interests and further embed dataist logics in 
education and research. Google enables different sorts of universities to emerge by lowering the costs of entry (as seen in online-only courses that depend heavily on Google's architecture), but whether this will lead to a pluralistic educational commons, or simply the deeper commodification of education remains to be seen. ${ }^{1 x x}$ And if it does lead to deeper commodification then this neoliberal strategy will deepen inequalities and intersecting oppressions in the social field - thus furthering the re-entrenchment of patriarchy.

\section{Struggling Over Patriarchy}

Dataism and the privatisation of knowledge, combined with a primarily white and Asian male workforce and the decontextualizing of information from its cultural location, all function to uphold and reinforce specifically racialized patriarchal structures. GoogleAlphabet is a corporation and the alt-right is an online network (partly hosted by this monopoly); they are different kinds of entities. Nevertheless, the way that these two emerging forms of power in the digital conjuncture are so successful in their exclusionary effects is striking. Google's organisation of women is an effect of its ideology of dataism and its epistemic architecture, as well as its work cultures. And whereas it (in its workplace) pretends to organise women in such a way that might offer them a beneficial position within their patriarchal hierarchy, Damore (and his allies) argue that women should be organised so that they are denied authority. Women can be kept out of the offices of Silicon Valley's corporations by overt or covert sexual and racial harassment, hostile work cultures, or discriminatory recruitment practices, as has been documented by Ellen Pao, Emily Chang, Susan Fowler, Kaya Thomas, and others. ${ }^{\mid{ }^{\mid x i}}$ In the rhetorical and visual culture of online spaces these exclusionary strategies become more visually extreme, and indicative of 'rape culture'. Ixxii In other words, whereas the tech industry is segregated and stratified along the lines of race and gender by formal and informal work practices, in online cultures these exclusionary practices are exaggerated and amplified, harnessing the hyperbolic language recorded by Emma A. Jane. ${ }^{\text {Ixxiii }}$

In our discussion of patriarchy, we follow Kate Manne's definition as it helps to explain why there was such a furore over the sacking Damore. Manne argues that: 
a social milieu counts as patriarchal insofar as certain kinds of institutions or social structures both proliferate and enjoy widespread support within it - from, for example, the state, as well as broader cultural sources, such as material resources, communal values, cultural narratives, media and artistic depictions, and so on. These patriarchal institutions will vary widely in their material and structural, as well as their social, features. But they will be such that all or most women are positioned as subordinate in relation to some man or men therein, the latter of whom are thereby (by the same token) dominant over the former, on the basis of their genders (among other relevant intersecting factors). (Manne, 45)

Complete suppression doesn't have to be successful in order for an institution or corporation to be patriarchal; it just needs to tend towards this suppression. In addition, 'these relations of domination and subordination are often local to a particular patriarchal structure and the individuals therein'. This means 'a man may be the master of his domain but subordinated, exploited, or marginalized in other contexts'. Ixxiv This is key because the anxiety over marginalisation in relation to the power and reach of the tech industry galvanises the misogyny of the alt-right.

Indeed we can see the struggle between the alt-right and Google as a struggle for a place in the patriarchal hierarchy. Damore's memo participates in pervasive discourses around the crisis of white masculinity; discourses that are located in the political and cultural mainstream. It is the articulation of this perceived crisis to the liberal stronghold of Google that gave him purchase in both the mainstream media and alt-right circles leading to his instant online fame. This is a crisis that the alt-right, has a deep investment in; indeed, it provides a foundation for its politics of hostility. What is interesting about these discourses is that, although they might critique men in powerful positions, they would recoil from analysing class exploitation, and would not necessarily bring to the fore the concept of patriarchy. Instead they prefer to blame women, trans people and people of colour for the disenfranchisement of some white men from the American dream. As Hamilton Carroll argues in his book on the new formations of white masculinity, 'We might ask not only why the disparities between white and minority earnings are invisible to white men, but also 
why the gulf between the low- and high-wage earners among white men is equally invisible. ${ }^{\mid x x v}$

In her discussion of the 'fun-house mirror' of popular feminism and popular misogyny, both of which circulate and compete in an 'economy of visibility', Banet-Weiser discusses how “injuries' dealt to masculinity and whiteness are seen as in need of repair and recuperation'. Ixvi Indeed, this is what drives much of the fandom around Damore. Damore stands in for the apparently victimised white man; victimised that is by diversity policies that threaten his place in a patriarchal structure. We can see the Damore memes express both a homosocial anxiety over white men's position in Google (or Big Tech's) patriarchal structure. This is directed at Google, but also at the women, trans people, and people of colour who might supersede the Damores of this world, but who can never replace Page and Brin as the founders of the company. The marshalling of Damore is a form of homosocial competition where white men are competing over the form digital capitalism's ideologies will take.

However, it is also a form of gatekeeping. Given a slightly different chronology, there is no reason why Damore couldn't have been part of the Paypal Mafia, Ixvvii a founder of Google or Facebook and so on. He is utterly typical of the white, technically educated, albeit at prestigious schools, male caste who dominate the companies of Silicon Valley and the wider West Coast tech economy. Indeed, Damore attacks diversity initiatives at Google because they imply that his title as Google engineer was not achieved by participating in a meritocratic system. This is why he is so invested in forms of knowledge that give biological justification for discrimination on the basis of gender. Ideologies rooted in evolutionary psychology suggest that he is rightfully positioned in a site of privilege. Drawing on literature that universalises claims about gender and sex from particularised case studies or experiments, Damore is able to argue that women are, on average, biologically hard-wired to be lesser engineers. Following the logics of dataism, Damore makes these claims in a general way, without context. Or, more importantly, he doesn't frame his sources as originating in specific and highly contentious academic discourses. Evolutionary psychology is a discipline that has been subject to numerous feminist critiques. ${ }^{\text {Ixxviii }}$ For instance, the anthropologist Susan McKinnon robustly denounces it as a means to bolster late capitalism's rampant individualism with a biological inevitability. Damore's memo is 
presumably compelling because it both taps into, and is revealing of, the prevailing commonsense around power, biological difference and the natural impulse to Hobbesian competition and violence typical to societies organised around capital accumulation. More than this, it gives contemporary patriarchy an inevitability as it is scientifically underpinned.

Manne's definition of misogyny and its relation to sexism and patriarchy is useful here. Manne argues that 'misogyny upholds the social norms of patriarchies by policing and patrolling them; whereas sexism serves to justify these norms - largely via an ideology of supposedly 'natural' differences between men and women with respect to their talents, interests, proclivities, and appetites.' We could understand the patriarchal structures of Google to be sexist and Damore's memo is protecting this sexism when he perceives it as under threat. We can understand Damore's employment of dataism as sexist also. However, the anxiety that pervades the memo (in relation to strange equivalence of homeless men and women in tech for example) obviously appeals to and is marshalled by the popular misogyny of the alt-right. As Manne argues: 'Misogyny taken alone involves anxieties, fears, and desires to maintain a patriarchal order, and a commitment to restoring it when it is disrupted. [...]. Sexism is bookish; misogyny is combative."1xxix

Damore primarily looks at gender in his memo, focusing on the apparent biological differences between men and women. But why are women in this case taken up as the point of conflict between Google, Damore and his allies? In this article, we have suggested that the preservation of a specifically racialized form of patriarchy is at the heart of this supposed struggle. The struggle might be over power, but we can understand Damore's memo and the following way that he was taken up by the alt-right as a rigorous form of gatekeeping. Damore is supposedly 'fired for truth', for speaking truth to power, but the problem for Damore and the sections of the alt-right that support him is not the power of Google itself, but that Google might be idiotic enough to introduce initiatives that threaten its patriarchal structure. Support for the memo is in the service of gatekeeping the tech industry's workplaces, as well as policing which groups will be on the ascendant according to the shifting forces of power that are occurring within the digital conjuncture. In other words, if Google and the alt-right have points of alliance - particularly in terms of sexist and racist epistemic architectures - then the struggle that is taking place as triggered by the 
memo, seems to be a struggle over its racial logics as well as how to organise women. Online misogyny is not a niche practice. It is a key site of the contemporary political terrain and, as Debbie Ging, argues it is the inevitable outcome of postfeminism which itself was a response to feminist struggle. ${ }^{\text {Ixx }}$ As Ging and Eugenia Siapera point out, online misogyny makes visible pervasive misogynies both online and offline. More than this, it functions to control women and keep them out of public space by doing them harm. ${ }^{1 \times x i}$

It is important not to overstate the importance of James Damore as an historical actor. What is significant is how he has been used by the alt-right and rejected by Google, indicating a fault line that only partially exists between conservatives and the tech industry. Returning to our Reformation analogy, while it offered up useful questions, the analogy between Luther and Damore must be seen as opportunistic propaganda in this struggle, as well as a desire to find a white male hero to determine history. It was a hundred years before Luther himself was made the central figure of the Reformation and there are already far more likely candidates for that role in digital capitalism than the disgraced Googler. But the memo and the meme are instructive from within the sensibilities of conjunctural analysis. It is through this approach that we can see how the conflicts within Silicon Valley's ideology of dataism tracethe links between the tech barons and the alt-right, the righteous princes and unruly mob, at a time of profound socio-cultural transformation. A conjunctural analysis is useful here because it allows us to zoom out and observe the factions jostling for power in the social and political shifts taking place in this period of digital capitalism, while still taking their actions, statements and interests into account. From this perspective, we can see patriarchy as a form of hierarchical power attempting to consolidate, preserve and protect itself. The detail of Damore's memo is useful in revealing this. Partly because it is overtly gatekeeping patriarchal structures in its appropriation of evolutionary psychology as scientific truth. Partly because the scale of the furore over the memo is revealing. But mostly because our analysis reveals that Google engages in this conflict not to challenge patriarchal power, but instead to jostle for position within it and over its shape, contours, hierarchies and stratifications. In such a way, an important part of the digital conjuncture can be seen as a struggle over the future of patriarchy, and particularly its racial and gendered logics. 
'Annie Kelly, 'The alt-right: reactionary rehabilitation for white masculinity', Soundings \#66, p. 69.
ii Sarah Banet Weiser, Empowered: Popular Feminism and Popular Misogyny, Durham, Duke University Press, 2018.

iii His personal website is called www.firedfortruth.com and @fired4truth was James Damore's twitter handle in the aftermath of the sacking.

iv https://www.blog.google/topics/diversity/note-employees-ceo-sundar-pichai/

$\checkmark$ Julie Bort, 'Over half of Google employees polled say the web giant shouldn't have fired the engineer behind the controversial memo', Business Insider UK, 10 Aug 2017, available at http://uk.businessinsider.com/manygoogle-employees-dont-think-james-damore-should-have-been-fired-2017-8

viSam Levin, 'James Damore, Google, and the YouTube radicalization of angry white men', The Guardian 13 Aug 2017, available at https://www.theguardian.com/technology/2017/aug/13/james-damore-google-memoyoutube-white-men-radicalization

vii Antonio Gramsci Selections from the Prison Notebooks ed. Quentin Hoare, London, Lawrence and Wishart 2005; See for instance the collected volume Stuart Hall, Doreen Massey and Mike Rustin (eds.) After

Neoliberalism: The Kilburn Manifesto London, Lawrence and Wishart 2015

viii Stuart Hall 'The Great Moving Right Show' Marxism Today January 1979

ix Jo Littler, 'On not being at CCCS' in Kieran Connell and Matthew Hilton (eds.), Cultural Studies 50 Years on:

History, Practice and Politics, London, Rowmen and Littlefield, 2016, p278.

× Doreen Massey and Michael Rustin, 'Displacing Neoliberalism', in Hall, Massey and Rustin (eds), After

Neoliberalism: The Kilburn Manifesto, London, Lawrence and Wishart, p. 199.

xi Sally Davison, David Featherstone and Bill Schwartz, 'Introduction', Stuart Hall: Political Writing, London, Lawrence and Wishart, 2017, p.15.

xii Robin Murray, Co-operation in the Age of Google report for Cooperatives UK available at:

https://www.uk.coop/sites/default/files/uploads/attachments/co-operation in the age of google.pdf

xiii Doreen Massey, 'Ideology and economics in the present moment', The Neoliberal Crisis, London, Lawrence and Wishart, 2015, p 103.

xiv Jose Van Dijck, J. Poell, T. and De Waal, M., The Platform Society: Public Values in a Connective World, Oxford, Oxford University Press, 2018.

${ }^{x v}$ Shoshona Zuboff, The Age of Surveillance Capitalism: The Fight for a Human Future at the New Frontier of Power, New York, Public Affairs, 2019.

xvi See Benjamin Bratton for an account of how the global significance of these tech companies could be understood. The Stack: On Software and Sovereignty Boston, MIT Press, 2016.

xvii Jodi Dean, Crowds and Party, London, Verso, 2016.

xviii Patricia Hill Collins and Sirma Bilge, Intersectionality, Cambridge, Polity, 2016.

xix Ben Little and Alison Winch, “"just hanging out with you in my back yard": Mark Zuckerberg and Mediated Paternalism', Open Cultural Studies, 1(1), 2017, pp417-427.

${ }^{\times x}$ Maria Mies, Patriarchy and Accumulation on a World Scale: Women in the International Division of Labour, Basinstoke, Palgrave, 1986.

xxi Safiya Umoja Noble, Algorithms of Oppression: How Search Engines Reinforce Racism, New York, New York University Press, 2018.

xxii Christian Fuchs, Social Media: A Critical introduction, London, Sage, p.17.

xxiii Siva Vaidhyanathan, The Googlization of Everything Berkeley, University of California Press, 2012; Franklin Foer, World Without Mind: The Existential Threat of Big Tech London, Penguin, 2017; Richard L. Brandt The Google Guys New York, Penguin 2011.

xxiv Banet-Weiser, Empowered; Catherine Rottenberg, The Rise of Neoliberal Feminism, Oxford, Oxford

University Press, 2018.

xxv Kelly, 'The Alt-Right', p. 69.

xxvi James Davison Hunter, Culture Wars: The Struggle to Define America, New York, Basic Books, 1991.

xxvii 'We're in the early stages of a radical transformation of our information environment. It's happening on a scale that has only been matched once before in history - when Johannes Gutenberg invented printing (or at any rate re-invented it in Europe). The print revolution transformed Western society and shaped the world in which - at least until recently - most of us grew up. The digital revolution is going to be just as far-reaching. So it's worth trying to trigger some serious discussions about what's happening and what may lie ahead' John Naughton 'About' 95theses.co.uk/?page_i=14

xxviii John Naughton 'Challenging Earthly Powers' 95theses.co.uk/?page_id=20

xxix Andrew Pettegree, Brand Luther, New York, Penguin, 2015. 
xxx Marshall McLuhan, The Gutenberg Galaxy, Toronto, University of Toronto Press, 1962.

xxxi Andrew Petegree, Brand Luther, New York, Penguin, 2015.

xxxii James Damore www.firedfortruth.com

xxxiii Noble, Algorithms of Oppression, pp. 164-5.

xxxiv Peter H. Diamandis and Steven Kotler Abundance: The Future is better than you think New York, Free Press, 2014.

xxxv Noble Algorithms of Oppression p. 148

xxvilibid p150

xxxvii bell hooks, 'Understanding Patriarchy' No Borders: Louisville's Radical Lending Library

http://imaginenoborders.org/pdf/zines/UnderstandingPatriarchy.pdf

xxxviii Vaidhyanathan, Googlization of Everything, p. 17.

xxxix Vaidhyanathan, Googlization of Everything, p. 60.

xl John Perry Barlow 'Declaration of the independence of cyberspace' https://www.eff.org/cyberspace-

independence

${ }^{x l i}$ Henry Jenkins Convergence culture : where old and new media collide New York, New York University Press, 2006.

xlii Imani Perry, Vexy Things: On Gender and Liberation, Durham, Duke University Press, 2018.

xliii James Damore https://firedfortruth.com/

xliv bell hooks, 'Understanding Patriarchy' No Borders: Louisville's Radical Lending Library

http://imaginenoborders.org/pdf/zines/UnderstandingPatriarchy.pdf

xlv These sources are often allied to the 'new atheism' movement, an online subculture that moves between islamophobia and hyper-rationality while claiming a form of "classical liberal" centrism. It places great weight on the thought of academics like Stephen Pinker, Richard Dawkins and similar.

xivi Emily Chang, Brotopia: Breaking up the boys club of Silicon Valley, New York, Portfolio, 2018, pp85-86.

xlvii Loretta Leea, http://unicorntechie.com/

xviii Christian Fuchs, Social Media, pp165-169/

xlix Richard Brandt, Google Guys; Laszlo Bock Work Rules! Insights from inside Google which will transform how you live and lead, London, John Murray, 2016.

'Tanza Loudenback and Drake Baer, 'The 20 schools with the most alumni at Google', Business Insider UK 4 September 2015 available at http://uk.businessinsider.com/schools-with-the-most-alumni-at-google-201510 ? $r=U S \& I R=T$

Ii Julia Carrie Wong, 'Segregated Valley: The ugly truth about Google and diversity in tech', The Guardian 7 August 2017 available at: https://www.theguardian.com/technology/2017/aug/07/silicon-valley-googlediversity-black-women-workers

lii https://www.google.com/diversity/index.html

liii Ellen McGirt, 'Google Searches for its Soul', Fortune 1 February 2017, available at: http://fortune.com/google-diversity/

liv David McAndless, 'Diversity in Tech', Information is Beautiful available at: '

https://informationisbeautiful.net/visualizations/diversity-in-tech/

"v Sara Ahmed, Living a Feminist Life, Durham, Duke University Press, 2017, p. 90.

Ivi Randall Stross, The Launch Pad: Inside Y Combinator, Silicon Valley's most exclusive school for startups, London, Penguin, 2012, p. 55.

Ivii José Van Dijck, 'Datafication, dataism and dataveillance: Big Data between scientific paradigm and ideology', Surveillance \& Society 12(2), 2014, p.198.

Iviii Lazlo Bock, How Google Works, p138.

lix https://strategicsamurai.com/

${ }^{1 x}$ Eric Schmidt and Jonathan Rosenberg, How Google Works, London, John Murray, 2014, p.152.

Ixi Gillian Bolsover and Philip Howard, 'Computational Propaganda and Political Big Data: Moving Toward a More Critical Research Agenda', Big Data, Vol 5 issue 4, (2017) p. 275.

Ixii Schmidt and Rosenberg How Google Works, pp.152-155.

Ixiii Ibid, p.151.

IxivTimothy B. Lee, 'Google fired James Damore for a controversial gender memo-now he's suing' arstechnica

9 January 2018 available at: https://arstechnica.com/tech-policy/2018/01/lawsuit-goes-after-alleged-anticonservative-bias-at-google/

Ixv Richard Brandt, The Google Guys, London, Penguin, 2011, p.61.

Ixvi Sara Ahmed, 'A Phenomenology of Whiteness', Feminist Theory 2007 8: 149. DOI:

$10.1177 / 1464700107078139 \mathrm{~F}$ 
Ixvii 'The University of Google lacks accreditation, to be sure... Poor searches by faithful Google users are only part of the problem with the Googlization of knowledge. The ways that Google structures, judges, and delivers knowledge to exacerbate our worst tendencies to jump to erroneous conclusions and act on them in ways that cause harm.' Vaidhyanathan Googlization of Everything, p. 78.

Ixviii Ryan Craig, College Disrupted: The Great Unbundling of Higher Education, Basingstoke, Palgrave, 2015.

rxix Colin Crouch, The Strange Non-death of Neoliberalism, Cambridge, Polity 2011.

Ixx We suspect the latter is more likely without the emergence radical movement to push for the former.

Ixxi Ellen Pao Reset: My Fight for Inclusion and Lasting Change New York, Random House 2017; Maureen Dowd, 'Susan Fowler: The Uber whistleblower that spoke out about sexual harassment in Silicon Valley' The Independent 1 November 2017; Kaya Thomas 'The Diverse Talent Pool Exists. Facebook Just Isn't Hiring Us'. Splinter. 15 July 2016. Available at: https://splinternews.com/the-diverse-talent-pool-exists-facebook-just-isnthiri-1793860279.

Ixxii See, for example, Jessalynn Keller, Kaitlynn Mendes \& Jessica Ringrose Speaking 'unspeakable things': documenting digital feminist responses to rape culture, Journal of Gender Studies, 27:1, 2016, pp22-36.

Ixxiii Emma A. Jane "Your a Ugly, Whorish, Slut", Feminist Media Studies, 14:4, 2012, pp531-546; Emma Alice Jane 'Back to the kitchen, cunt': speaking the unspeakable about online misogyny, Continuum, 28:4, 2014, pp.558-570.

Ixxiv Manne, Down Girl p. 45.

Ixxv Hamilton Carroll, Affirmative Reaction: New Formations of White Masculinity, Durham, Duke University Press 2011, p.5.

Ixxvi Banet-Weiser, Empowered, p. 32.

IxvviiThe group of men who made their fortunes from selling paypal to eBay and went on to found and fund some of the more successful Silicon Valley companies. See Eric Jackson The PayPal Wars, Washington, WND Books, 2012.

Ixxviii Rachel O'Neill, 'Feminist Encounters with Evolutionary Psychology', Australian Feminist Studies, 30:86, 2016, 345-350; Meyers, D. T., 'FEAST Cluster on Feminist Critiques of Evolutionary Psychology-Editor's Introduction.' Hypatia, 27, 2012, 1-2.

Ixxix Manne, Down Girl, p. 88.

Ixxx Debbie Ging, 'Digital violence in the Manosphere: technology, affect, and the future of gender politics' Keynote at University of East Anglia, 18 September 2018.

Ixxxi Debbie Ging and Eugenia Siapera, 'Editorial to Special Issue on Online Misogyny' Feminist Media Studies, vol. 18, no. 4, 515-524. 2018. https://doi.org/10.1080/14680777.2018.1447345 